\title{
Internal mechanisms of persuasion
}

\author{
Bianca Teodorescu \\ University of Craiova, 13 A. I. Cuza Street, Craiova, 200585, Romania \\ E-mail address: teodorescumbianca@yahoo.com
}

\begin{abstract}
By persuasion we understand the action to convince someone to do something that we want to achieve our aims. The person who accepts the other's opinions without any real evidence can be easily persuaded. Persuasion is a form of influence. It is a modality of argumentation through a person is trying to convince another person or a group of people to believe the false evidence. The persuasion is a process which is based on people in order to adopt attitudes or rational and irrational actions relying on a persuasive speech instead using means of force.
\end{abstract}

Keywords: persuasion; communication; lie; myth; seduction; fiction

\section{INTRODUCTION}

The persuasion is a form of communication which has as a main principle in changing people's thoughts, or attitudes by creating a new type of inducement in order to control the objectives that we wanted. Changing attitudes, moral conduct and behavior are the persuasion's aims who are performing on false or true evidence. Conviction has two parts: conviction and persuasion: if the first appears only when someone is trying to convince another person with true evidence, the second leads to persuade with false evidence. In this case, a person who is rifted by others opinions, hoping that he will find the right answers, will always have problems in creating his own opinion. In other words, the individual is exposed poisoning by the other's opinions, even if he has attainable problems. Between conviction and persuasion is a difference made by the diversity of the means. Conviction sustains the used means and not the final result and persuasion are relying on the power to obtain the chosen result. Another difference is that the perception follows, forcing the action. Persuasion has an obvious and charming final result besides conviction because she is counting on an immoral action (Borowski, 2014). Conviction is corresponding to a communication act witch wants to modificate a person's mental state in a freedom context. The freedom action belongs to a target and is an essential component of a convective interaction. A behavior which depends on an exterior oppression can lead to an opposite effect. An important factor of conviction is that she isn't always efficient because she is limited in time and uneconomical (Perelman, 1958). 


\section{PERSUASION AND LANGUAGE}

We learn from the time we are born to follow the rules to prevent breaking the law in our society. A man is constantly influenced by the things around him and the environment is the main factor that influenced a man how to act and react to the events that are taking place in his life. One of the reasons of persuasion that affects our society is the language because from the moment since we say the first word, we are closely influenced by the society in which we live and obey the rules (Enachescu, 2013; Siminică \& Traistaru, 2013). However, our society persuades us in all aspects of life. To convince someone means to influence the intellectual, but the main factor is to submit and to be liked by the person or group who you want to be persuaded. In order to obtain the desired effect, it's important to know that a person is in his inward soul is rational and spontaneous too. The persuasion has the power to change everything inside of the people's opinions and attitudes relying on different forms of social influence: social facilitation, forming a new group of rules, conformism, minority influence, imitation, obedience and Ringelmann effect. The absence of an argument inside of persuasion doesn't equal with the absence of any other reason. There are two theses that support the act of persuasion (Borowski, 2013). The first thesis belongs to Sigmund Freud, the father of psychoanalysis, which he says that people are in essence libidinal by nature. Freud is focusing on an idea that every man wants to find in another man an ideal idol with the same aspirations like his. The second thesis is relying on Turner's paper about the desire of a person to belong in a group with common values and the same lifestyle as his.

To persuade a mass of people, it's not necessary to be against their ideals. The most important things about the persuasion are that we must know how to dominate the art of communication and to sustain the people, so that we can catch their trust. Then, when they are feeling safe with us, we must make sure that we can loosely inoculate our ideas in a manner to change their mind. However, it's important that every time we must guess the feelings that we are generate to avoid developing other problems.

\section{HOW IS ARTICULATED PERSUASION}

The meaning of a lie is to distort the truth in order to deceive another person (Dziwańska, 2013). When a person is lying, she doesn't stand as a liar. In a fundamental society, the lie is a necessity. A lie is the result of a person's state of mind which has as purpose the desire to influence others (Strechie, 2014; Iorgulescu, 2014). The liar tracks to reach a target, but sometimes it can happen that the lie-target can be actually the liar himself with an eye to avert from the certain problems and to face easier the reality. In this situation, we can say that the lie protects the liar. But to have credibility, a person has to believe half of what he is lying with a faultless speech. The lie can be made in the name of a person or an institution and it provides fictional information (Dima \& Vlăduţescu, 2012).

In the act of persuasion, the lie has two subspecies: simulation and dissimulation. The simulation is a model for behavior where it's pursuing the benefits or the achievements of a person. Simulation is equal with opportunism.

Dissimulation means spreading the rumors in order to mask the interests focused on uprightness and stability, leading to betrayal.

The myth have persuasive qualities. The word etymology comes from the Greek "mythos" which means narration. "The myth is a communication system, a message" (Barthes, 1970). Everything can be a myth because the universe is unlimited. From this is resulting that 
the myth is unlimited. The myth has three particularity: a pronounced blurring language, an ambiguous knowledge and a deformed guileful motivation. The persuasion is based on the power that she has over the messages sent (Păun, 2013; Păun, 2014).

Persuasion starts to work in fiction when the lie and myth are starting to carry off. The fiction and the myth are both narration but the first structures reality on the possible edge. A difference between them is the purpose; the fiction transforms the present. An example of fiction is the mass media (Țenescu, 2009; Țenescu, 2011; Stavre, 2012). Here, the journalist tends to form the news in a negative way for a major impact. We can say that the reality is replaced with the fiction. In order to create confusion, the journalist instals a border between him and the public. From the news to have an impact over the public, a journalist must know four things: framing- establishment a subject, focalisation-concentration over the subject, realisation-induct the fiction on the message and closure the news with further possibility to create another news with the same story.

A seductive speech can be achieved with a proper language and mind. It's important for a seductive action to have a body language. A person has to know that the seduction has some features: smile, easiness, appearances development and the most important thing in this case, morality doesn't exist (Ficeac, 2001).

The art of illusion is created by the seduction in order to pursuit self improvement. The most important factor of seduction is the flattery and the importance that she has over the destinantary in reaching a new foreign emotions .In this case, the seducer must disclaim the honesty. The seduction scheme is a simple one: the seducer exploits and influences the recipient, so that the seduced won't find the truth. The strategy of this action is to change the banal things into extraordinary. Seduction has an evil base (Baudrillard, 1987). She denies the truth and acts in a persuasive mode. There are a few forms of seduction in a manner to lead the in the persuasive action (Enachescu, Hristache \& Paicu, 2012; Mangra, Cotoc \& Traistaru, 2013).

Persuasion has many moral problems and one of them is the influence. The responsible persuasive action is relying on stimulation over the target group. In order that the persuasion to have effects, we must know what are the needs, beliefs, wishes of the group.

Conviction or responsible persuasion means the idea to create a persuasive action with a moral cause. For a responsible persuasion to have a success it must rely on: both persons to have equal chances and the same persuasive ability, access at al communication resources, to know the other's purposes and both to be a critical receptives, capable to confirm or deny the evidence presented (Larson, 2003; Drămnescu, 2013).

The principal object of persuasion is to change someone's opinion. But, besides changing the opinion are another objects to follow: changing the attitudes, moral conduct and behavior. The first task is ordering the others. Although the social understanding is closely marked by the person's moral behavior, every person has the right to have his own opinion, even if is it correct or not. A person's natural opinion isn't superficial or changeable, because she is more solid the more she belongs to a stronger group. In this case, the opinions are less contradictory only in a critical situation like a war or a political quarrel, because this conflict only introduces the individual opinion in a broad group.

The world is directly proportional with the man, the evolution is closely related to them. A man is a social and political person, but a producer of culture and civilization too; everything depends on humanity (Borowski, 2013, 2014). The man is creating the world after his own imagination. A man is permanently influenced by the things around him. The principal factor that affects a man in the action of persuade is the environment. He is in a continuous evolution 
in descovering the humanity and the mode how he organizes his daily life (Bărbulescu, Ţâţu \& Ţâţu, 2007).

In the communication speech, the needs of a person are in fact aims and interests. To have a clean knowledge, the information comes to satisfy and to realize the desired answers in manner to solve the uncertainty. A value which is influenced by the need appears only in a person or a group's selective behavior.

But what is the need of communication? We can say that she is a selection of what we take the information from the messages in order to make a choice that it influences our life. However, we want to communicate because we want to be informated by what is happens in the society which we live. This need of communication is given by an interior momentum, but she is marked by our intelligence. It's important to know that the lack of communication is a disease. If we won't communicate, our society will be gone.

A conviction and persuasion speech is using argumentation and demonstration in the communicative act. The ideas are justify by the different logical procedures. The argumentation is based on strategy or tehnics wish leads to conviction. She has a fundamental impartial process, but the demonstration is a form of argumentation that follows a high conviction performance. The argumentation of a persuasive communication is ineffective and can be bad chosen in sustaining a cause by the person who wants to persuade. But, instead, the demonstration has a scientific guaranteed, which it only can be refused (Bitoleanu, 2014; Ionescu \& Pretorian, 2014; Gîfu, 2014). Because of that, argumentation can be contested and the demonstration not. If the argumentation is more liberal than the demonstration, it means that the choice of a strategy is representated by the destinantary. The demonstration is restrictive and she forces to control the action.

\section{CONCLUSION}

The persuasion has the role to transform us into a powerful people capable to play with the mind of the others. She has to do, not only with people's beliefs, but with their values, interests, needs, or even with their skills. We need persuasion in our life because it's an important action that can convince our children the importance of education, our superiors or colleagues that we have the best idea, our friends to have trust in us or our lovers to know that we are deeply in love with them. Persuasion represents our capacity to influence the people's beliefs and actions.

\section{References}

[1] Andrzej Borowski, International Letters of Social and Humanistic Sciences 11 (2014) $1-168$.

[2] Alex Mucchielli (2002). Arta de a influenţa. Iaşi: Polirom. [3] Charles U. Larson (2003). Persuasiunea. Receptare şi responsabilitate. Iaşi: Polirom.

[3] Enachescu V. A., Journal of Community Positive Practices, 13(2) (2013).

[4] A. Borowski, International Letters of Social and Humanistic Sciences 3 (2013) 69-74.

[5] Jean Baudrillard (1987). L'autre par lui meme. Paris: Galilée. 
[6] A. Borowski, International Letters of Social and Humanistic Sciences 4 (2013) 70-74.

[7] Chaim Perelman, Lucie Olbtrechts-Tyteca (1958). Traité de l'argumentation. La nouvelle rhétorique. Paris: PUF.

[8] Andrzej Borowski, International Letters of Socia and Humanistic Sciences 2 (2014) 110-121.

[9] M. G. Mangra, E. A. Cotoc, A. Traistaru (2013). Sustainable Economic Development Through Environmental Management Systems Implementation. Journal.

[10] Roland Barthes (1970). Mythologies. Paris: Seuil.

[11] Enachescu V. A., Hristache D. A., Paicu C. E., Review of Applied Socio-Economic Research 4(2) (2012) 93-96.

[12] Marin Drămnescu (2013). Postmodern Society and Individual Alienation. Revista de PSIHOterapie Experienţială.â

[13] Țenescu A. (2009). Comunicare, sens, discurs. Craiova: Editura Universitaria.

[14] J. Tittenbrun, International Letters of Social and Humanistic Sciences 2 (2014) 20-40.

[15] I. C. Dima, Ş. Vlăduţescu (2012). Persuasion elements used in logistical negotiation: Persuasive logistical negotiation. Saarbrucken: LAP Lambert Academic Publishing.

[16] A. Borowski, International Letters of Social and Humanistic Sciences 4 (2013) 70-74.

[17] Mihaela Gabriela Paun (2013). Changes in Management as an Instrument of Educational Intervention. European.

[18] Mihaela-Gabriela Păun, International Letters of Social and Humanistic Sciences 6 (2014) 42-48.

[19] Jason L. Powell, International Letters of Social and Humanistic Sciences 7 (2014) 22-30.

[20] A. Borowski, International Letters of Social and Humanistic Sciences 6 (2013) 86-90.

[21] Marian Siminică, Aurelia Traistaru (2013). Self-Directed Learning in Economic Education. International.

[22] Kinga Dziwańska, International Letters of Social and Humanistic Sciences 7 (2013) 96-112.

[23] Stefan Freytag, International Letters of Social and Humanistic Sciences 10 (2013) 25-31.

[24] I. Stavre (2012). Internet and digital technology - influences on audiovisual communication and on teaching at master's degree level, Valencia, 2012, Published by International Association of Technology, Education and Development ISBN: 97884-615-5563-5

[25] Iulian Bitoleanu, International Letters of Social and Humanistic Sciences 9 (2014) 161-121.

[26] Dan Ionescu, Cristina Pretorian, International Letters of Social and Humanistic Sciences 9 (2014) 49-56. 
[27] Bogdan Ficeac (2001). Tehnici de manipulare. Ediţia a patra. Bucureşti: Nemira.

[28] Mădălina Strechie, International Letters of Social and Humanistic Sciences 7 (2014) 56-61.

[29] R. Bărbulescu, D. Ţâţu, L. Ţâtu (2007). Investment in human capital. EU integration opportunities, Romania within EU: opportunities, requirements and perspectives (pp. 430-435). V1. Sibiu: Editura Universităţii Lucian Blaga.

[30] Alexandra Iorgulescu, International Letters of Social and Humanistic Sciences 7 (2014) 14-21.

[31] Tenescu A., Annales Universitatis Apulensis. Series Philologica 12(2) (2011) 235-250.

[32] Donovan A. McFarlane, International Letters of Social and Humanistic Sciences 4 (2013) 35-44.

[33] Daniela Gîfu (2014). Temeliile Turnului Babel. O perspectivă integratoare asupra discursului public. Bucureşti: Editura Academiei Române.

[34] A. Borowski, International Letters of Social and Humanistic Sciences 2 (2013) 56-60.

[35] Peter Emerson, International Letters of Social and Humanistic Sciences 10(2) (2014) 132-155. 